УДК 552.513:552.144:551.3.051

\title{
УСЛОВИЯ ФОРМИРОВАНИЯ ПЕСЧАНЫХ ПЛАСТОВ-КОЛЛЕКТОРОВ ЯКОВЛЕВСКОЙ СВИТЫ НА ТЕРРИТОРИИ ЛОДОЧНОГО НЕФТЕГАЗОКОНДЕНСАТНОГО МЕСТОРОЖДЕНИЯ
}

\author{
Черданцева Дарья Андреевна 1 , \\ cherdantsevada@tomsknipi.ru
}

\section{Кравченко Григорий Геннадьевич 1 ,} kravchenkogg@tomsknipi.ru

\author{
Краснощекова Любовь Афанасьевна², \\ krasnl@tpu.ru \\ 1 Акционерное общество «Томский научно-исследовательский и проектный институт нефти и газа», \\ Россия, 634027, г. Томск, пр. Мира, 72. \\ 2 Национальный исследовательский Томский политехнический университет, \\ Россия, 634050, г. Томск, пр. Ленина, 30.
}

\begin{abstract}
Актуальность исследования обусловлена необходимостью расщирения ресурсного потенциала Российской Федерации за счет прироста месторождений углеводородов. На сегодняшний день нефоть относится к полезным ископаемьм, достигнутые уровни добычи которых недостаточно обеспечены запасами разрабатываемых месторождений. Подробное изучение строения продуктивных песчаных пластов-коллекторов в пределах Ванкорской группы месторождений на севере Красноярского края в перспективе даст возможность для прогноза и открытия новых залежей углеводородов в нижнемеловых отложениях Сибири.

Цель: определить условия формирования продуктивных песчаных пластов по данным изучения кернового материала, изучить причины неоднородности сформированных отложений и выявить их характернье признаки для последующего прогноза нижнемеловых нефртеносных отложений на территории Красноярского края.

объект: продуктивные песчаные пласты яковлевской свиты нижнего мела Лодочного нефртегазоконденсатного месторождения.

Методы: петрографический анализ шлифов, стадиальный анализ, гранулометрический анализ, фрациальный анализ, исследование фильтрационно-емкостных и петрофизических свойств пород.

Результаты. По данным петрографического анализа был изучен вещественный состав продуктивных песчаных отложений верхне- и нижнеяковлевской подсвит Лодочного месторождения, дана их сравнительная характеристика. Определена степень влияния постседиментационных процессов на формирование современного облика изучаемых отложений. Предложена фрациальная модель, наиболее точно описывающая условия формирования продуктивных пластов. Установлено влияние условий осадконакопления в комплексе с последующими постседиментационными преобразованиями пород на фильтрационно-емкостные параметры песчаников. Объяснены причины наличия карбонатизированных прослоев во фрлювиальных отложениях. Сделаны выводы о возможности прогноза продуктивности отложений яковлевской свиты, накопленных в различных фациальных обстановках.
\end{abstract}

Ключевые слова:

Песчаник, диагенез, яковлевская свита, аллювиальная обстановка, Красноярский край.

\section{Введение}

Лодочное нефтегазоконденсатное месторождение входит в Ванкорскую группу месторождений углеводородов и административно расположено в Туруханском районе Красноярского края, с точки зрения нефтегазогеологического районирования относится к Большехетскому нефтегазоносному району ПурТазовской нефтегазоносной области. Север Красноярского края является перспективной территорией для наращивания нефтегазового потенциала РФ. Изучаемое месторождение многопластовое, основные запасы углеводородов приурочены к нижнемеловым отложениям яковлевской, малохетской, суходудинской и нижнехетской свит. Яковлевская свита по своему литологическому составу разделена на две подсвиты нижнюю угленосную и верхнюю песчано-глинистую.

Целью исследования являлось установление условий формирования и анализ причин неоднородности свойств терригенных пластов-коллекторов вышеуказанной сви- ты для последующего прогноза и моделирования особенностей строения песчаных тел на месторождении.

В работах отечественных $[1,2]$ и зарубежных $[3,4]$ седиментологов, связанных с исследованием терригенных пород, применяется комплексное изучение вещественного состава, условий формирования и диагенетических преобразований пород [5-7]. Все чаще эти исследования дополняются прецизионными методами: электронной микроскопией $[8,9]$, рентгенофазовыми исследованиями [10].

При проведении петрографических исследований в каждом конкретном случае наблюдению доступны лишь конечные или промежуточные продукты полистадийного литогенеза [11]. Для раскрытия информации о стадиях и условиях формирования отложений, зашифрованной в образцах, необходимо путём снятия вторичных наслоений определить первичные признаки осадка, из которого была сформирована порода [12]. При этом через изучение признаков последовательно- 
сти этапов формирования, изменения и исчезновения в породе минеральных и структурно-текстурных парагенезисов минералов, с учётом всех сопутствующих геологических событий на исследуемой территории, возможно обоснование неоднородности строения продуктивных пластов и, как следствие, получение данных для построения максимально приближенных к реальности моделей месторождения.

В статье приведены результаты комплексного изучения песчаных пластов яковлевской свиты от макроскопического исследования керна до петрографического анализа шлифов. Авторами предпринята попытка реконструкции последовательности процессов, оказавших влияние на исследуемые породы на разных стадиях их формирования и трансформации через проведение морфологической и генетической типизации слоистых текстур и изучение вещественного состава пород.

\section{Объекты и методы исследований}

Объектом настоящих исследований выступили песчаные пласты яковлевской свиты, вскрытые скважинами 9, 10, 13, 14, 128 Лодочного месторождения. Всего было изучено 1375 м кернового материала и 305 прокрашенных синей эпоксидной смолой шлифов.

Фациальный анализ керна выполнялся по стандартным методикам, основу которых составляет детальное макроскопическое изучение особенностей строения пород в керновом материале [13-15].

При проведении фациального анализа учитывались следующие основные признаки осадочных пород:

1. Структурные и текстурные особенности их строения:

- осадочные структуры, отраженные в гранулометрическом составе (размер и форма зёрен, степень их сортировки и окатанность);

- осадочные текстуры и типы слоистости - горизонтальная, одно- и разнонаправленная косая, волнистая и их смешанные типы, градационная, троговая, линзовидная и т. д., включая также разнообразные неслоистые текстуры конседиментационных деформаций, оползания, внедрения, шаровые и подушечные, биотурбационные и др.

2. Палеонтологические признаки, такие как включения флоры и фауны, следы жизнедеятельности (ихнофациальный анализ).

3. Совокупность геохимических признаков (присутствие минералов-индикаторов: доломита и кальцита, сульфидов железа, глауконита, глинистых минералов и др.).

По совокупности вышеуказанных признаков возможно установление темпов седиментации, характерных для изучаемых пород.

Проведение фациального анализа состояло из двух крупных этапов: предварительного и аналитического. В процессе предварительного этапа авторы изучили особенности тектонического строения, стратиграфического расчленения и истории геологического развития месторождения. Результатом изучения стало определение основных предпосылок, составляющих так называемый «фациальный фон».
Аналитический этап включал в себя проведение самого фациального анализа, а именно:

1) послойное литологическое описание песчаных пород с использованием комплекса макро- и микроскопических анализов, а также различных химических и физических методов.

2) выделение «реперных» фаций, т. е. таких отложений, фациальная интерпретация которых однозначна, например, углей, почв, прослоев с органическими биоценозами, характерными только для определенных обстановок.

3) диагностика оставшихся отложений с выделением фаций путём анализа взаимоотношений различных литотипов, как по разрезу, так и по площади. Наиболее важным элементом этой стадии является выбор концептуальной модели, описывающей обстановки осадконакопления всех изучаемых отложений.

Петрографическое изучение включало определение структурно-текстурных характеристик, количественный гранулометрический и минералогический анализ в шлифах алевро-песчаных пород на поляризационном микроскопе Olympus BX53 по методике Черникова (1970). Для гранулометрического анализа измерялись длины случайных срезов для 200 зерен, последовательно пересеченных микрометренной линейкой окуляра микроскопа. Фракционный состав породы рассчитывался для фракций с соотношением границ равным 1,259 $\left({ }^{10} \sqrt{10}\right)$ с последующим пересчётом полученных содержаний в каждой фракции для устранения эффекта случайного срезания зёрен поверхностью шлифа [16]. При выделении гранулометрических песчаных фракций использовалась классификация, приведенная в Систематике и классификации осадочных пород (1998). Одновременно с гранулометрическим определением размеров зёрен проводилось определение состава терригенных компонентов [17], составляющих скелет породы, а именно: кварца, полевых шпатов и обломков различных пород, включая слюды. Название породы по составу приводилось по классификации В.Н. Шванова (1987). Помимо породообразующих минералов, определялся тип цементации и характер распространения цемента, поровое пространство характеризовалось по размерам, формам и закономерностям распределения. По результатам изучения делались выводы о вторичных изменениях, проявленных в породах.

\section{Результаты и их обсуждение}

Фациальные условия

Отложения нижнего отдела меловой системы в пределах Лодочного месторождения вскрыты 10 скважинами и представлены нижнехетской, суходудинской, малохетской и яковлевской свитами. Последняя по своему литологическому составу делится на верхнюю песчано-глинистую и нижнюю угленосную. К верхней подсвите отнесены продуктивные пласты ВЯк-I, ВЯк-V, ВЯк-VIII-IX, ВЯк-Х, ВЯк-ХІ, ВЯк-XV, ВЯк-XVII; к нижней - Як-I-II, Як-III, Як-IV, Як-V, Як-VI, Як-VII, Як-VIII.

Изученный авторами керновый материал из отложений яковлевской свиты представлен переслаивани- 
ем светло-серых глинистых и известковистых среднесцементированных песчаников (с полосчатым характером нефтенасыщения) с серыми песчаноглинистыми алевролитами и темно-серыми аргиллитами. Отмечаются единичные пропластки галечных песчаных пестроокрашенных гравелитов и углей. Основная текстура песчаников слоистая, для верхнеяковлевских отложений характерна слоистость волнистая и косоволнистая, для нижнеяковлевских - косая однонаправленная, подчёркнутая намывами углефицированного детрита, сидеритом; реже отмечаются биотурбационная и интракластовая текстуры. Для аргиллитов наиболее характерна линзовидная слоистость, подчёркнутая песчаным материалом; в качестве подчинённых встречаются оползневая, брекчиевидная, пятнистая и прожилковая текстуры.

В отложениях пласта Як-IV отмечается наличие сидеритовых и кальцитовых конкреций размером до 16 см в диаметре. По всему разрезу яковлевской свиты наблюдается неравномерная наложенная вторичная карбонатизация с преимущественно пятнистым и полосчато-пятнистым характером распределения. Интракласты, отмеченные в песчаных прослоях, по составу в большинстве случаев глинистые, реже сидеритовые. Часто в породах встречаются намывы углефицированного растительного детрита от тонких прослоев, подчёркивающих косую слоистость, до крупных (размером более 5 см) обрывков удлинённой формы.

Проведение морфологической типизации слоистости, по Л.Н. Ботвинкиной [18], с последующей генетической типизацией текстур позволили выделить основные фациальные обстановки, характерные для изучаемой территории на момент формирования яковлевской свиты. Каждая выделенная фация характеризуется не одним типом слоистости, а определённым комплексом слоистых текстур.

Для верхнеяковлевских отложений характерно наличие в песчаниках косоволнистой (мульдообразной) и линзовидно-косо-волнистой слоистости, что, наряду с преимущественно хорошей сортировкой материала, фиксирует высокую гидродинамическую активность среды осадкообразования. В частности, проявление волнистой слоистости говорит об активном волновом воздействии. Верхнеяковлевские отложения интенсивно биотурбированы, что однозначно указывает на значимую роль морской или осолонённой воды в ходе их седиментации, а присутствие в них отпечатков флоры и остатков корней - об аэральных или субаэральных условиях (близости континента).

Преобладание в разрезе нижнеяковлевской подсвиты косой плоскопараллельной и косой однонаправленной слоистости также свидетельствует об активной динамике среды, однако в этом случае она была связана преимущественно с однонаправленными потоками. Нередко встречающиеся в песчаниках скопления интракластов являются признаком частичного размыва нижележащих слабосцементированных отложений. Широкое распространение, по сравнению с верхнеяковлевской подсвитой, угольных прослоев, отпечатков флоры, остатков корней и углефицированного растительного детрита интерпретируется как результат более аэральных условий. Сортировка материала преимущественно хорошая и средняя, реже встречается плохая.

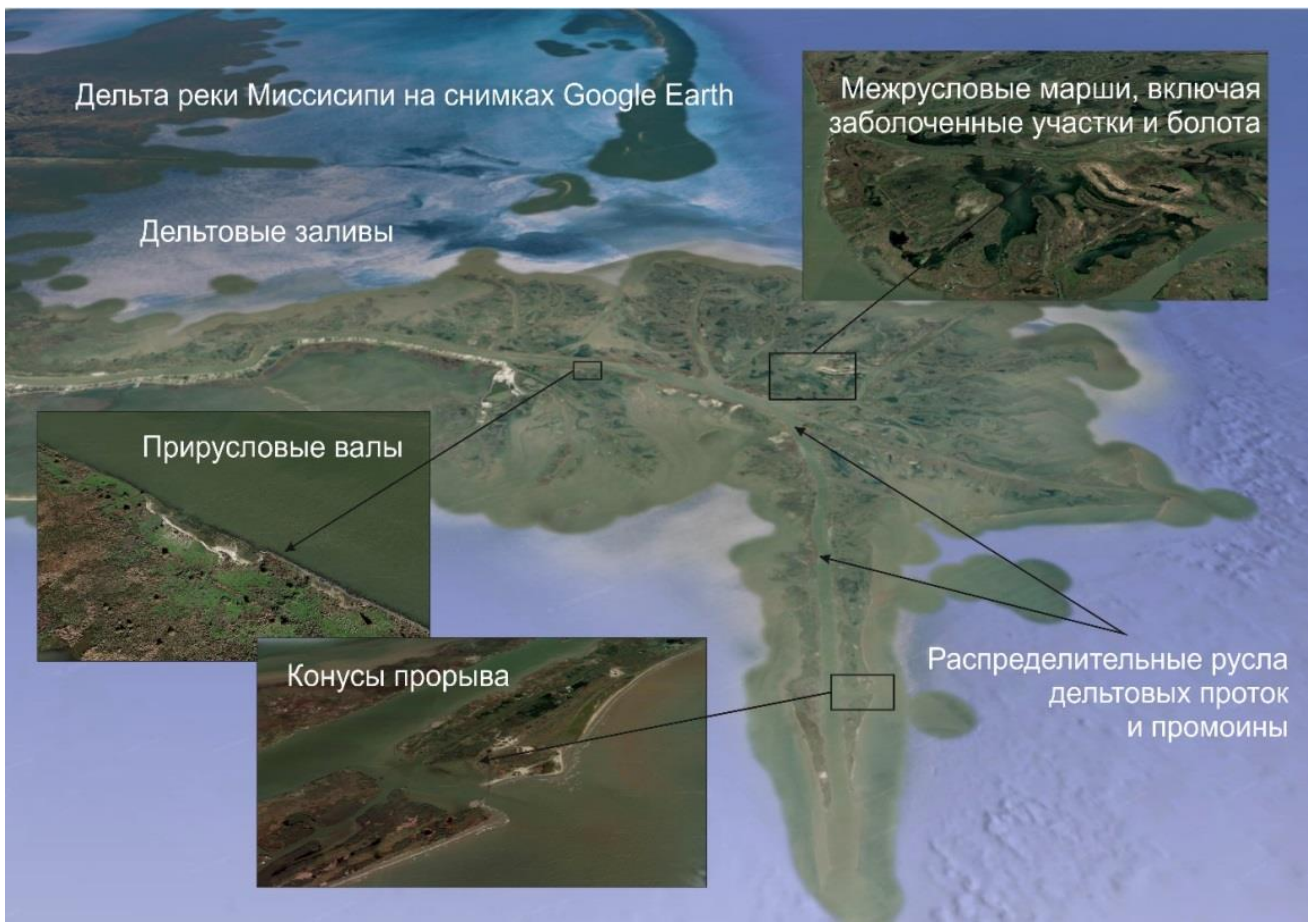

Pис. 1. Космический снимок (Google Earth) дельты реки Миссисипи. Современный аналог для принятой фациальной модели яковлевской свиты - дельта с преобладанием речных процессов и значительным выносом обломочного материала

Fig. 1. The Mississippi River Delta satellite image (Google Earth). A modern analogue for the Yakovlevskaya suite facies model is the delta with the river processes predominance and clastic material significant removal 
По результатам проведённого авторами фациального анализа установлено, что яковлевская свита представляет собой довольно однородную в фациальном отношении толщу: это набор фаций дельтовой системы (возможно, не одной) флювиального типа, отложение которых происходило в диапазоне от субаэральной до субаквальной части дельтовой равнины. Периодическое перемещение территории из субаэральной части дельтовой равнины в субаквальную и обратно происходило в условиях проградации дельты на фоне незначительных колебаний относительного уровня моря. Существенно более глинистый и углистый состав песчаных пластов верхней подсвиты - результат замедления проградации дельты и выравнивания территории и, как следствие, проникновения морских вод с последующим формированием сильно биотурбированных прослоев. На рис. 1 приведён пример современного аналога для выделенных фациальных обстановок осадконакопления, существующих на описываемой территории в период формирования яковлевской свиты.

Ниже рассмотрены краткие характеристики основных фаций, выделенных по керновому материалу яковлевской свиты из скважин Лодочного месторождения (рис. 2, 3).

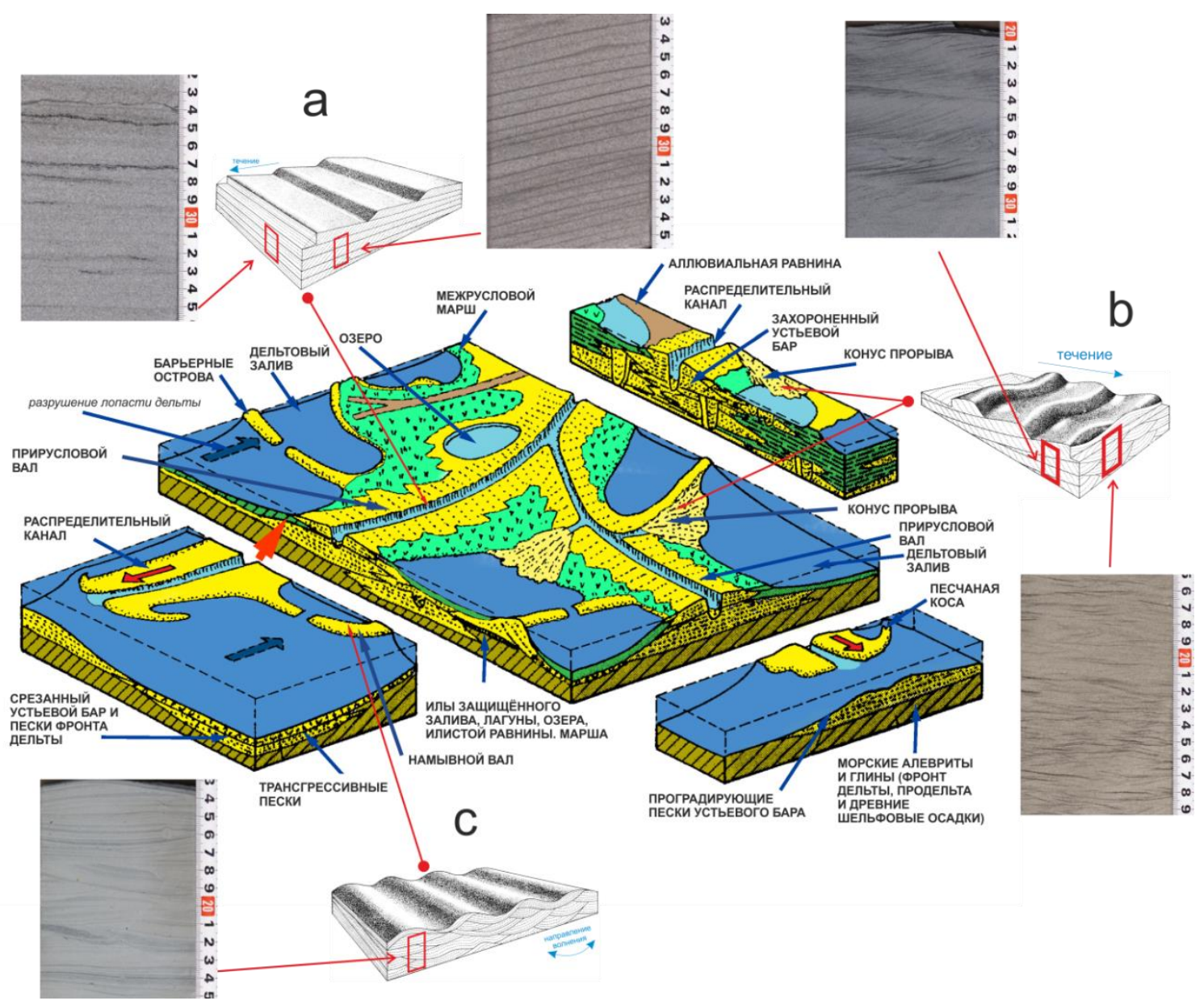

Рис. 2. Концептуальная схема дельты с преобладанием речных процессов (по G. Einsele [19], с дополнениями Е.Ю. Барабошкина [13], с изменениями авторов). Блок-диаграммы косой слоистости [14], демонстрирующие внутреннее строение песчаных пород с: а) косой (плоскопараллельной, табулярной) слоистостью, образованной при миграчии ряби течения с прямолинейными гребнями; на фрагментах фотографий керна - песчаники фачии русла распределительного канала; $b$ ) косой слоистостью, образованной при миграчии мелкой волнистой ряби; на фрагментах фотографий керна - песчаники фации конуса прорыва; с) ассиметричной рябью волнения; на фрагменте фотографии керна - песчаник фации намывного вала в дельтовом заливе, 6 песчанике отмечается разнонаправленная косая слоистость ряби волнения с перекрещиванием, выклиниванием и срезанием косых слойков

Fig. 2. Conceptual scheme of the delta with the river processes predominance (according to G. Einsele [19], with additions by E.Yu. Baraboshkin [13], with changes by the authors). Bedded structure block-diagrams [14], showing the sandstone layers internal structure with: a) diagonal stratification (plane-parallel, tabular) formed during migration of the current ripples with straight ripple crest; the core photo fragments show sandstones from the distribution channel; b) oblique stratification formed during the small wavy ripples migration; the core photo fragments show sandstones from the crevasse splay; c) asymmetric wave lamination; the core photofragment shows the sandstone from the natural levee facies in the delta bay; in the sandstone there is multidirectional oblique ripple stratification with crossing, pinching and cutting of oblique layers 


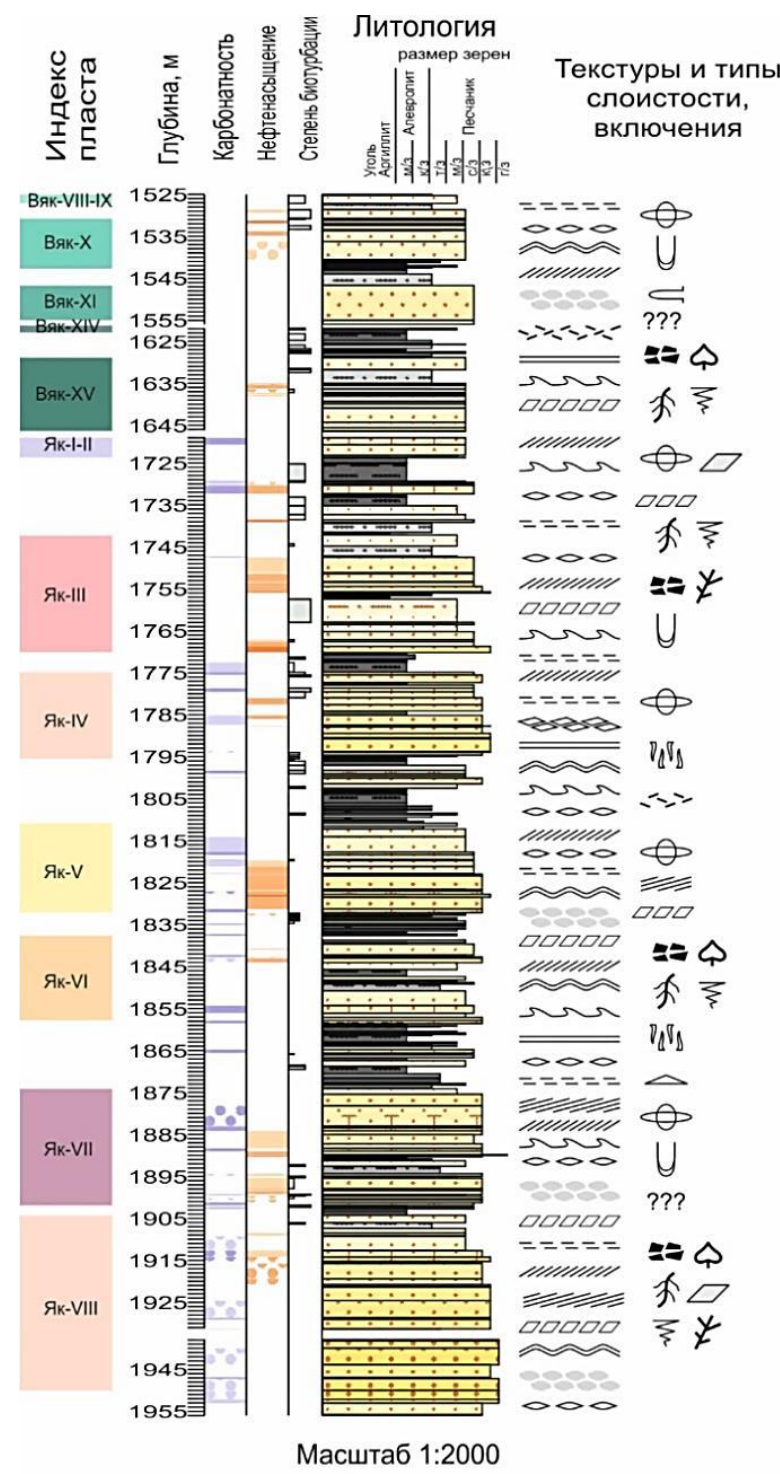

Условные обозначения для литологической колонки

\begin{tabular}{|c|c|c|c|c|c|c|}
\hline $\begin{array}{c}\text { название } \\
\text { породы }\end{array}$ & 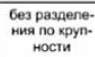 & 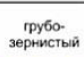 & $\begin{array}{c}\text { крупно- } \\
\text { зернистый }\end{array}$ & $\begin{array}{c}\text { средне- } \\
\text { зернистый }\end{array}$ & $\begin{array}{c}\text { мелюко- } \\
\text { зеринстый }\end{array}$ & $\begin{array}{l}\text { гонко- } \\
\text { зернистьй }\end{array}$ \\
\hline песчаник & & $\because \because \because \because$ & $\because \because \because \because$ & $\because \because \because$ & $\therefore 1$ & \\
\hline алевролит & & & $8 \div \div \div$ & $8 \div \div \div$ & $E \div \div \div 3$ & \\
\hline аргиллит & $=-$ & & & & & \\
\hline уголь & & & & & & \\
\hline
\end{tabular}

Следы жизнедеятельности, органические остатки отпечатки и включения

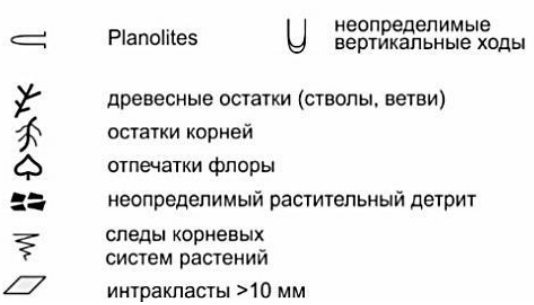

Рис. 3. Литологическая колонка и основные типь слоистых текстур и фаций по разрезу яковлевской свиты. Скважина № 9 Лодочного месторождения

Fig. 3. Lithological column and the layered structures main types with facies along the Yakovlevskaya suite section, well No. 9 of the Lodochnoe oil and gas field
Фациальные обстановки осадконакопления Дельтовый залив
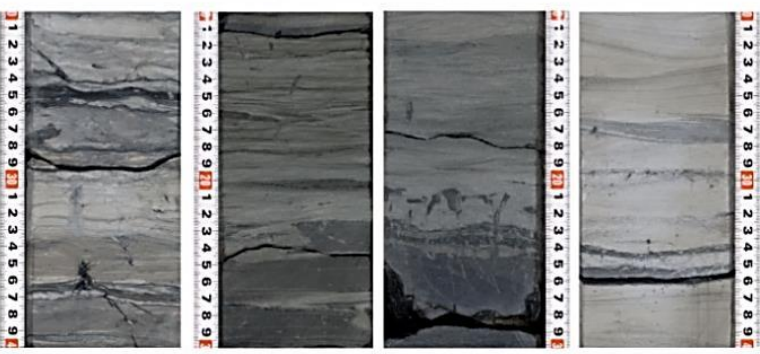

Распределительные русла

Прирусловые валы
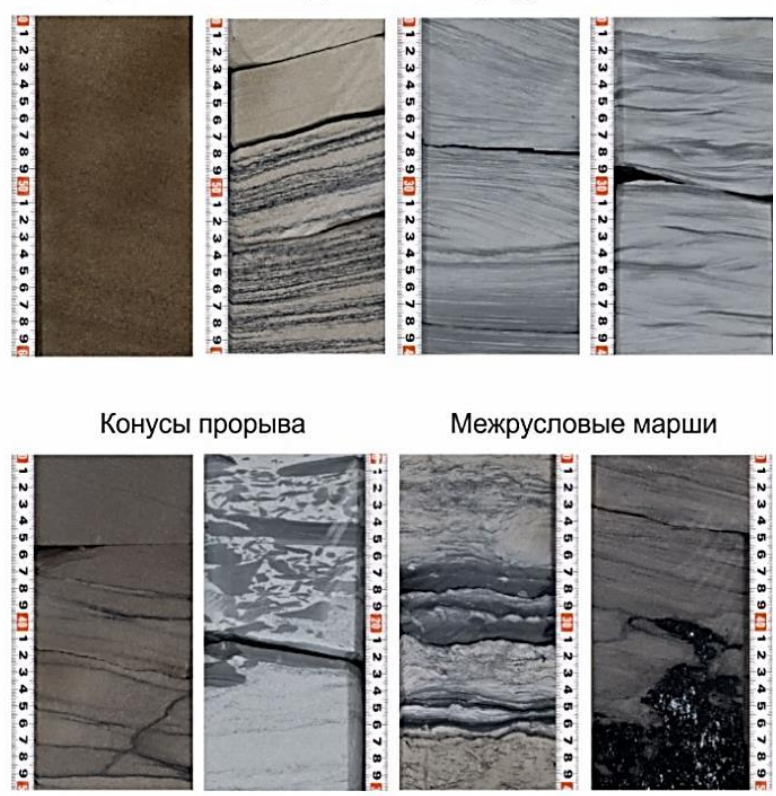

Межрусловые марши
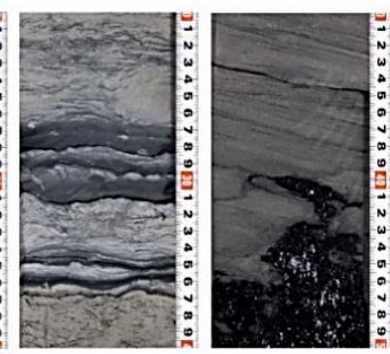

$\begin{array}{ll}\text { основные второсте- } & \begin{array}{l}\text { Текстуры и типы слоистости } \\ \text { пенные }\end{array}\end{array}$

Карбонатность Нефтенасыщенность керна сплошная пятнистая полосчатая сплошная пятнистая полосчатая

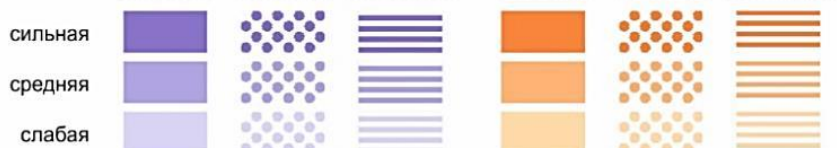

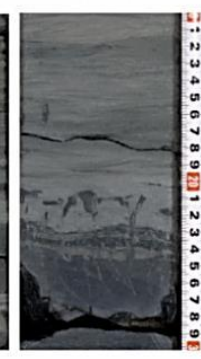


Фация распределительных русел дельтовых проток и промоин представлена мелко- и среднезернистыми песчаниками, толщина пропластков которых достигает 10 м. Наиболее распространённый тип слоистости - косая однонаправленная, участками встречается её разновидность - плоскопараллельная (рис. 2,a), что указывает на формирование отложений в условиях однонаправленного потока. Слоистость не выдержана, как по форме и толщине слойков, так и по мощности серий, что дополнительно свидетельствует о частой смене скоростей руслового потока, в отличие от гораздо более однородных потоков рек меандрирующего типа. Встречаются глинистые интракласты и обломки углефицированной древесины, фиксирующие поверхности врезания (русловые врезы), особенно характерные для нижней подсвиты. Песчаники фации русел обладают наилучшими коллекторскими свойствами среди всех песчаных отложений других фаций, выделенных авторами в яковлевской свите на месторождении.

Фация прирусловых валов представлена мелкотонкозернистыми песчаниками, часто алевритовыми и глинистыми, или тонким ритмичным переслаиванием этих пород. Встречаются ихнофоссилии (субаквальное накопление) и углефицированные корни и следы их присутствия - обычно в верхней части разрезов прирусловых валов (аэральная обстановка).

Фациия конусов прорыва сложена тонкомелкозернистыми песчаниками с однонаправленной косой слоистостью (в поперечных срезах она может иметь вид троговой или мульдообразной), нередко с подчёркнутой обильными глинистыми намывами восходящей рябью течения, что является признаком большого количества влекомого потоком обломочного материала (рис. 2, b). Для конусов прорыва характерна ассоциация с межрусловыми маршами и дельтовым заливом. Мощность конусов прорыва - от не- скольких десятков сантиметров до первых метров. Песчаники этой фации также могут быть хорошими коллекторами для УВ.

Фация межрусловых маршей содержит в основном глинистые отложения, нередко встречается их переслаивание с песчаниками конусов прорыва. Наличие прослоев с ихнофоссилиями указывает на подтопление территории солоноватыми водами из-за близости моря. Также отмечаются тонкие прослои углей или углистых аргиллитов, которые фиксируют периоды заболачивания территории. Иногда в алевролитах наблюдаются подушечные текстуры - результат продавливания песчаным осадком менее плотного слабо литифицированного алевритового ила, что интерпретируется как признак аквальных условий.

Фация дельтовых заливов представлена неравномерным переслаиванием песчано-глинистых пород, в которых фиксируются многочисленные ихнофоссилии. На этапе формирования описываемой фации на изучаемой территории, по-видимому, преобладали субаквальные условия с опреснением, о чём свидетельствует широкое распространение ихнофоссилий Teichichnus. Встречаются прослои мелкозернистого песчаника с разнонаправленной косой слоистостью ряби волнения, которые также могут являться коллекторами для УВ (рис. 2, c).

\section{Вещественный состав и постседиментационные преобразования отложений}

В результате петрографического анализа образцов были подсчитаны обобщённые литологические характеристики для песчаников нижне- и верхнеяковлевской подсвит, полученные данные отражены в таблице ниже. По соотношениям основных породообразующих компонентов песчаные породы яковлевской свиты относятся к мезомиктовым песчаникам, аркозам и кварцевым грауваккам (рис. 4).

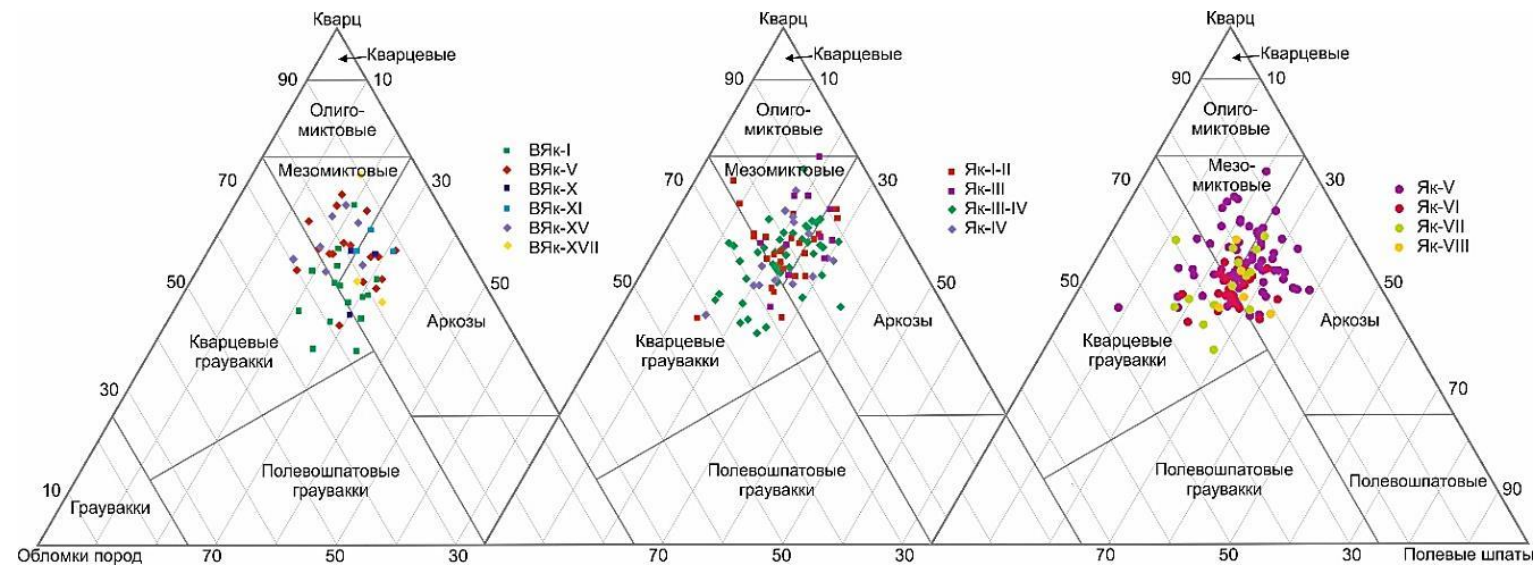

Pис. 4. Состав песчаных пород верхне- и нижнеяковлевской подсвит на диаграмме В.Н. Шванова (1987)

Fig. 4. Sandstone composition diagrams according to V.N. Shvanov (1987), sandstones from Upper and Lower Yakovlevskaya suite oil-bearing layers

Основная микротекстура пород ориентированная, обусловленная субпараллельным расположением удлинённых обломков и чешуек слюд, подчёркнутая послойным обогащением породы органическим веществом, рудными и акцессорными минералами. По- мимо основной ориентированной микротекстуры в песчаниках отмечены:

- неяснослоистая текстура, сформированная за счёт неравномерного послойного распределения карбонатного цемента и карбонатно-глинистых прослоев; 
- яснослоистая текстура, возникающая за счёт прослоев, обогащенных глауконитом, хлоритом, сидеритом, слюдами, органическим веществом и рудными минералами;
- пятнистая микротекстура, связанная с неравномерным распределением карбонатного цемента (рис. 5)
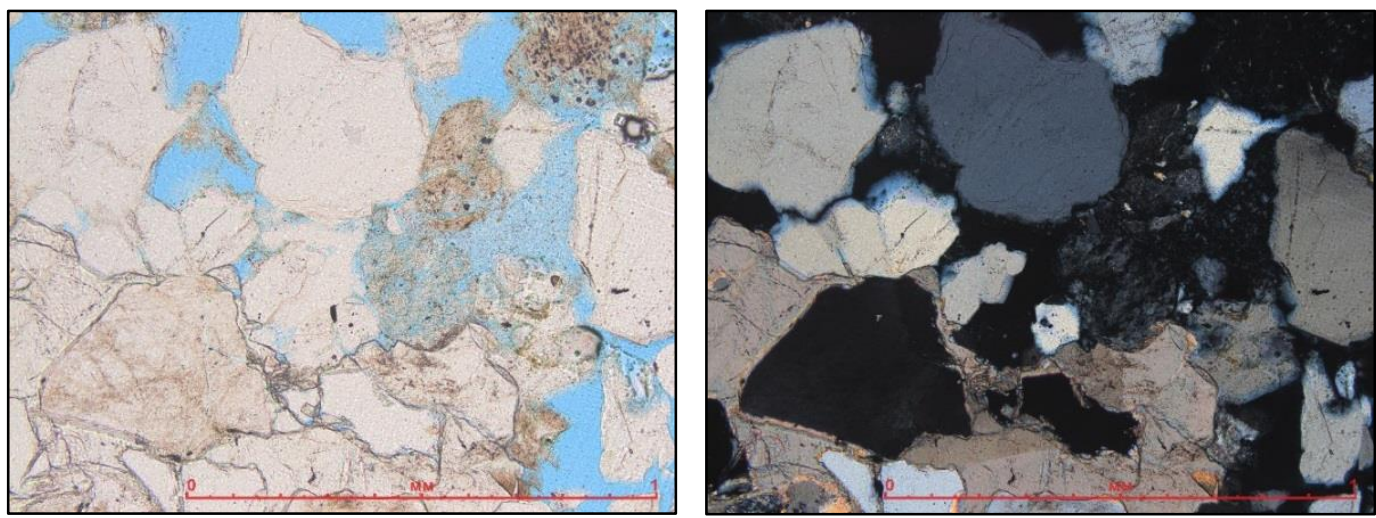

Pис. 5. Песчаник с пятнистой микротекстурой среднезернистый мезомиктовый с коррозионно-поровым карбонатным и поровым каолинитовым иементом. Фотоснимок илифа № 1786-19 скв. № 9, глубина отбора 1941,2 м, пласт Як-VIII. Николи параллельны и скрещеень

Fig. 5. Medium-grained mesomictic sandstone with spotty microtexture and porous corrosion carbonate and kaolinite cement. Thin section photo, sample No. 1786-19, well No. 9, sampling depth 1941,2 m, layer Yak-VIII. In planepolarized light on left, cross-polarized light on right

Кварцевые зёрна имеют разную степень окатанности, фрагментарно отмечается регенерация минерала и его разрастание за счёт каёмок в свободном поровом пространстве. Калиевые полевые шпаты подвержены умеренной пелитизации и каолинитизации, плагиоклазы слабо серицитизированы с фрагментарным проявлением альбитизации. При растворении полевых шпатов формируется внутризерновая микропористость.

Обломки пород в песчаниках из верхне- и нижнеяковлевской подсвит имеют гетерогенное происхождение и представлены, преимущественно, кварцитами, кварц-серицитовыми и глинистыми сланцами, обломками кремнистых и углисто-слюдисто-кремнистых пород, метавулканитами основного состава. Различие в составе обломков пород изучаемых отложений проявляется незначительно: в верхнеяковлевских песчаниках единично фиксируются, помимо указанных выше, обломки карбонатных пород, в нижнеяковлевских - обломки гранитоидов, в единичных случаях алевролитов.

Слюды в породах гидратируются, по биотиту фиксируется развитие сидерита и хлорита, вплоть до полного его замещения.

Из акцессорных минералов встречаются рутил, циркон, турмалин, сфен, гранат, апатит, минералы группы эпидота, хромит и магнетит. Из аутигенных образований наблюдаются лейкоксен, глауконит и пирит, карбонатные и глинистые минералы.

Механическое уплотнение в изучаемых песчаниках проявлено слабо, на что указывают преобладающие типы контактов зёрен - точечные и линейные, реже отмечаются конформные и инкорпорационные. Последние по [20] проявляются при повышении нагрузки вышележащих толщ пород на терригенный материал в присутствии водно-флюидной фазы на стадии катагенеза и приводят к возникновению минеральных агрегатов с минимальными зазорами и вы- пукло-вогнутыми и взаимопроникающими контактами между зернами.

Распределение цемента в породах неравномерное: в одних участках шлифа цементы полиминеральные, сложены глинистыми минералами, карбонатами, сульфидами; в других участках перечисленные минералы проявляются раздельно и формируют мономинеральный цемент.

Глинистые цементы порового и пленочнопорового типа представлены чешуйками гидрослюды, хлоритом и каолинитом. Количественная оценка содержания глинистых минералов проводилась при петрографическом изучении пород в шлифах (таблица). Гидрослюды развиты преимущественно в виде мелкочешуйчато-волокнистых агрегатов, хлорит образует цемент порового выполнения.

Каолинит занимает поры между обломками и в большинстве случаев имеет хорошо выраженную мелко-среднекристаллическую структуру. Локально наблюдается перекристаллизация первичного гидрослюдистого цемента с образованием чешуйчатого каолинитового агрегата. В межпакетных промежутках в каолините распространены микропоры. Образование каолинита в песчаниках можно связать с эпигенетическими процессами, обусловленными изменением гидрогеологического режима. В результате чего в пласты проникали чужеродные по химизму воды, контактировавшие с нефтяными залежами и твёрдыми битумами. Повышенная кислотность вод стимулировала развитие аутигенного каолинита за счёт образования его кристаллических агрегатов в поровом пространстве из растворов, содержащих диффундировавшие ионы $\mathrm{Si}^{4+}$ и $\mathrm{Al}^{3+}$ от минералов-доноров. Избирательная альбитизация и частичное растворение плагиоклазов привели к высвобождению ионов $\mathrm{Ca}^{+}$и $\mathrm{K}^{+}$, и свободные ионы $\mathrm{Ca}^{+}$ пополнили в поровом пространстве резерв для формирования аутигенных карбонатов. 
Таблица. Сравнительная характеристика литологических параметров песчаных пластов верхне- и нижнеяковлевской подсвит

Table. Sandstones material composition comparative characteristics (samples from the Upper and Lower Yakovlevskaya subsuites)

\begin{tabular}{|c|c|c|c|c|}
\hline \multicolumn{3}{|c|}{ Подсвита/Subsuite } & $\begin{array}{l}\text { Верхнеяковлевская } \\
\text { Upper Yakovlevskaya }\end{array}$ & $\begin{array}{c}\text { Нижнеяковлевская } \\
\text { Lower } \\
\text { Yakovlevskaya }\end{array}$ \\
\hline \multicolumn{5}{|c|}{ Гранулометрические характеристики/Granulometric characteristics* } \\
\hline \multirow{4}{*}{\multicolumn{2}{|c|}{$\begin{array}{c}\text { Песчаные фракции, мм (распространённость } \\
\text { в условных единицах) } \\
\text { Sand fractions, mm (prevalence in conditional units) }\end{array}$}} & $\begin{array}{c}\text { тонкая } \\
\text { close }(0,05 \ldots 0,10) \\
\end{array}$ & + & - \\
\hline & & $\begin{array}{c}\text { мелкая } \\
\text { fine }(0,10 \ldots 0,25)\end{array}$ & +++ & +++ \\
\hline & & $\begin{array}{l}\text { средняя } \\
\text { medium } \\
(0,25 \ldots 0,50)\end{array}$ & +++ & +++ \\
\hline & & $\begin{array}{c}\text { крупная } \\
\text { coarse }(0,50 \ldots 1,00)\end{array}$ & + & - \\
\hline \multicolumn{3}{|c|}{$\begin{array}{l}\text { Средневзвешенный диаметр зёрен, мм } \\
\text { Weighted average grain diameter, mm }\end{array}$} & $\mathbf{0 , 3 2}(0,06 \ldots 0,57)$ & $\mathbf{0 , 2 4}(0,20 \ldots 0,27)$ \\
\hline \multirow{4}{*}{\multicolumn{2}{|c|}{$\begin{array}{l}\text { Степень сортировки } \\
\text { Sorting degree }\end{array}$}} & $\begin{array}{l}\text { очень хорошая } \\
\text { very good }\end{array}$ & ++ & + \\
\hline & & хорошая/good & +++ & +++ \\
\hline & & средняя/medium & ++ & +++ \\
\hline & & плохая/low & + & + \\
\hline \multicolumn{5}{|c|}{ Вещественный состав/The material composition** } \\
\hline \multicolumn{3}{|c|}{ Кварц/Quartz, \% } & $\mathbf{4 5 , 3}(33,2 \ldots 57,5)$ & $\mathbf{3 7 , 9}(34,1 \ldots 41,8)$ \\
\hline \multicolumn{3}{|c|}{ Полевые шпаты/Feldspars, \% } & $\mathbf{1 4 , 9}(9,9 \ldots 19,9)$ & $\mathbf{1 2 , 1}(7,6 \ldots 16,5)$ \\
\hline \multicolumn{3}{|c|}{$\begin{array}{c}\text { Среднее соотношение КПШ/Плагиоклазы } \\
\text { K-feldspar/plagioclase average ratio }\end{array}$} & $62 / 38$ & $60 / 40$ \\
\hline \multicolumn{3}{|c|}{ Обломки пород/Rock fragments, $\%$} & $\mathbf{1 0 , 1}(3,9 \ldots 16,4)$ & $\mathbf{2 7 , 8}(10,9 \ldots 17,0)$ \\
\hline \multirow{2}{*}{\multicolumn{2}{|c|}{ Слюды/Mica, \% }} & $\begin{array}{l}\text { Мусковит } \\
\text { Muscovite }\end{array}$ & $\mathbf{1 , 3}(0,4 \ldots 2,1)$ & $\mathbf{1 , 5}(0,9 \ldots 2,1)$ \\
\hline & & $\begin{array}{l}\text { Биотит } \\
\text { Biotite }\end{array}$ & $\mathbf{0 , 4}(0,1 \ldots 0,6)$ & $\mathbf{2 , 8}(1,2 \ldots 4,5)$ \\
\hline \multirow{3}{*}{\multicolumn{2}{|c|}{$\begin{array}{l}\text { Аутигенные минералы } \\
\text { (макс. содержание) } \\
\text { Authigenic minerals } \\
\text { (max. content), \% }\end{array}$}} & $\begin{array}{l}\text { Глауконит } \\
\text { Glauconite }\end{array}$ & $\mathbf{2 , 9}(0,4 \ldots 5,4)$ & $\mathbf{2 , 1}(0,3 \ldots 4,0)$ \\
\hline & & $\begin{array}{l}\text { Лейкоксен } \\
\text { Leucoxene }\end{array}$ & $\mathbf{1 , 4}(0,7 \ldots 2,0)$ & $\mathbf{0 , 5}(0,2 \ldots 0,8)$ \\
\hline & & $\begin{array}{l}\text { Пирит } \\
\text { Pyrite }\end{array}$ & $\mathbf{1 , 5}(0,1 \ldots 2,9)$ & $\mathbf{4 , 7}(0,1 \ldots 9,2)$ \\
\hline \multicolumn{3}{|c|}{ Акцессорные минералы/Accessory minerals, \% } & $\mathbf{0 , 9}(0,1 \ldots 1,6)$ & $\mathbf{1 , 3}(0,6 \ldots 2,1)$ \\
\hline \multirow{5}{*}{ 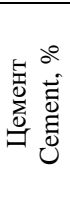 } & \multirow{3}{*}{$\begin{array}{l}\text { Поровый и плёночно-поровый } \\
\text { Pore and film-pore }\end{array}$} & $\begin{array}{l}\text { Каолинит } \\
\text { Kaolinite }\end{array}$ & $7,4(4,4 \ldots 10,5)$ & $\mathbf{1 1 , 9}(6,6 \ldots 17,1)$ \\
\hline & & Иллит|Illit & $\mathbf{1 , 3}(0,4 \ldots 2,2)$ & $\mathbf{3 , 2}(0,4 \ldots 6,0)$ \\
\hline & & Хлорит/Chlorite & $\mathbf{2 , 9}(0,1 \ldots 5,7)$ & $\mathbf{3 , 8}(1,2 \ldots 6,3)$ \\
\hline & \multirow{2}{*}{$\begin{array}{l}\text { Коррозионно-поровый } \\
\text { Corrosion-pore }\end{array}$} & Кальцит/Calcite & до 13,1 & $8,7(0,8 \ldots 16,7)$ \\
\hline & & Сидерит/Siderite & до 24,3 & $\mathbf{6 , 5}(0,3 \ldots 12,7)$ \\
\hline \multicolumn{3}{|c|}{ Органическое вещество/Organic matter, \% } & $\mathbf{1 , 4}(0,2 \ldots 2,6)$ & $\mathbf{6 , 5}(0,4 \ldots 12,6)$ \\
\hline \multicolumn{3}{|c|}{ Пористость/Porosity, \% } & $\mathbf{1 1 , 8}(5,0 \ldots 18,5)$ & $\mathbf{1 4 , 9}(12,3 \ldots 17,6)$ \\
\hline
\end{tabular}

*Здесь и далее полужирным шрифтом указаны средние (в скобках - минимальные и максимальные) значения;

**Содержания в \% от площуади шлифа.

* Here and below the average (in brackets - the minimum and maximum) values are given with bold font; ** Content in \% of the thin section surface.

Коррозионно-поровый карбонатный цемент имеет неоднородное распределение, представлен сидеритом и кальцитом, реже доломитом. Сидерит встречается в виде микроконкреционных стяжений пелитоморфного сложения, выделений, мелкокристаллической сыпи и сферолитов, конкреций. Кальцитовый цемент проявляется в отдельных изученных породах, при выполнении пространства между обломками образует поровый (рис. 6), реже базально-поровый тип цементации. Доломит в виде отдельных ромбовидных зерен развит незначительно.

Пиритовый цемент встречается постоянно. Преимущественно он состоит из скоплений тонких пылеватых зерен, фрагментарно встречается псевдомонокристальный цемент базально-порового типа.
Формирование карбонатного цемента с пятнистым распределением значительно снижает пористость и проницаемость песчаников, поскольку в таких участках пород пустоты (поры, трещины, соединительные канальца) запечатываются карбонатным веществом, что приводит к уменьшению их полезной емкости. Механизм вторичной карбонатизации аллювиальнодельтовых песчаных осадков, по-видимому, может быть связан с потерей $\mathrm{CO}_{2}$ в процессе его миграции при отжатии поровых растворов и последующей «вентиляции» из глин в пески, а затем в воду. Свободная углекислота совместно с растворами бикарбонатов кальция, магния и железа фильтровалась через породы в процессе их диагенетического преобразования. При 
падении давления $\mathrm{CO}_{2}$ происходило увеличение $\mathrm{pH}$ среды и, как следствие, осаждение бикарбонатов в терригенных породах [21].

Приуроченность сидерита $\left(\mathrm{FeCO}_{3}\right)$ к алевролитоглинистым прослоям, в меньшей степени к песчаным разновидностям, в изучаемых разрезах позволяет предположить, что его образование начинается на стадии диагенеза в еще неуплотненных или слабо уплот- нённых осадках, насыщенных железо- и кальцийсодержащими водами, что характерно для дельтовых болотных систем. Выделения сидерита в виде пелитоморфного агрегата, сферолитов (ранний диагенез) и конкреций (поздний диагенез) свидетельствует о некотором перераспределении вещества диагенетических минералов в позднем диагенезе из-за неравномерной концентрации растворов в разных частях осадка [22].
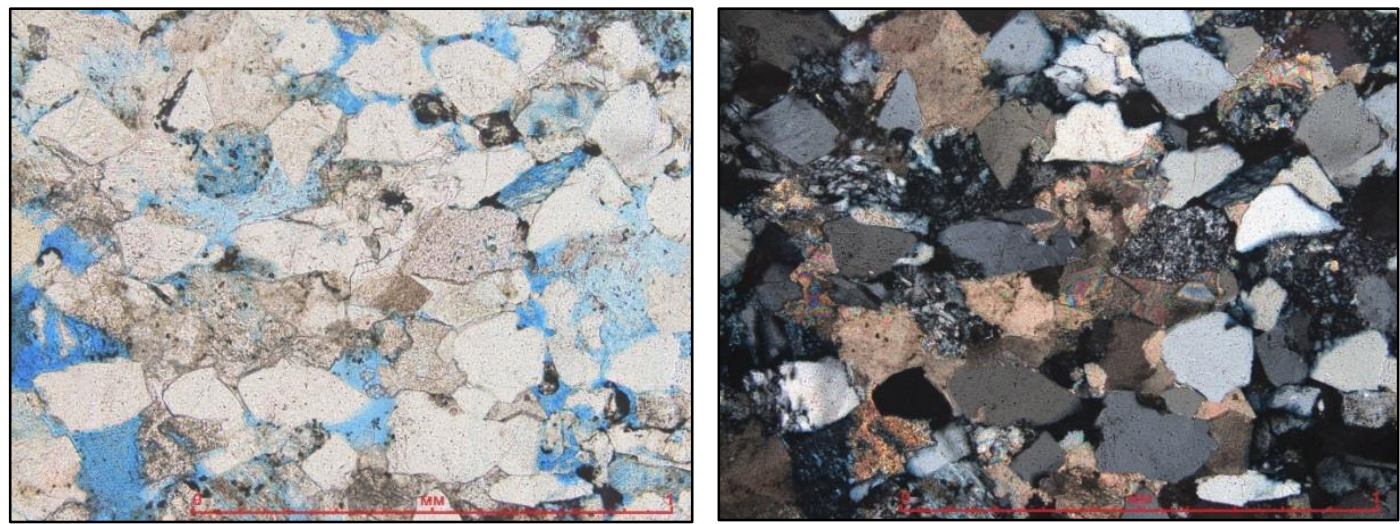

Рис. 6. Песчаник однородный средне-мелкозернистый мезомиктовый с каолинит-карбонатным иементом. Фотоснимок илифа № 4176-17 скв. № 128 к. 1, глубина отбора 1682,04 м, пласт ВЯк-V. Николи параллельны и скрещзеньл

Fig. 6. Medium-fine-grained mesomictic clay calcareous sandstone with kaolinite-carbonate cement. Thin section photo, sample No. 4176-17, well No. 128 c. 1, sampling depth $1682.04 \mathrm{~m}$, layer VYak-V. In plane-polarized light on left, cross-polarized light on right

Кальцит $\left(\mathrm{CaCO}_{3}\right)$ в песчаных породах распределен неравномерно, образуя пятнистые разновидности песчаников с карбонатным цементом, что может являться результатом проявления инфильтрационных либо эксфильтрационных притоков водных растворов, миграция которых обусловлена тектоническими процессами [23]. Миграция флюидов с растворенными компонентами, катионы которых имеют различную подвижность - железа, магния, кальция и марганца, из нижележащих залежей приводит к различной интенсивности вторичной карбонатизации в породах вышележащих пластов [24]. Помимо указанного выше процесса трансформации $\mathrm{CO}_{2}$ и его влияния на карбонатообразование, кальцит может образовываться и за счет растворения Са-содержащих минералов, например, плагиоклазов или хлоритов, что фиксируется в изученных породах. Неоднородное распределение в виде пятен вторичного кальцита в нижнемеловых отложениях Большехетской впадины отмечали также в [25].

Предлагаемые механизмы образования карбонатов яковлевской свиты позволяют объяснить их афациальность и неоднородное формирование в виде отдельных пятен и прослоев в аллювиальных дельтовых отложениях.

Изучение процессов цементации и уплотнения пород и последовательности диагенетических процессов в песчаниках [26, 27], а также условий преобразования минералов, входящих в их состав $[28,29]$, делает возможным объяснение причин неоднородности строения продуктивных пластов.

Органическое вещество представлено удлинёнными выделениями от чёрного до красно-бурого цвета, сгустками и примазками, встречается в виде обособлений с сетчатой (ячеистой) структурой и единичных полупрозрачных проявлений бурого цвета, часто совместно с сидеритом.

Пустотное пространство в шлифах представлено в основном межзерновыми порами, в меньшей степени наблюдается внутризерновая пористость, обусловленная растворением полевых шпатов и выщелачиванием компонентов обломков пород, и микропористость в каолините. Сообщающиеся и изолированные межзерновые поры имеют угловатую, субизометричную и заливообразную формы, их размеры варьируют от 0,1 до 0,5 мм.

Пористость пород, определённая по прокрашенным эпоксидной синей смолой шлифам, составляет от $1 \%$ в песчаниках с базальным карбонатным цементом до 27,4 \% в наиболее крупнозернистых песчаниках с каолинитовым цементом. На рис. 7 график соотношения пустотного пространства и цемента в изученных шлифах демонстрирует влияние карбонатного цемента на пористость. Так, в результате вторичной карбонатизации пород увеличение карбонатного цемента приводит к снижению пористости и, как следствие, к снижению проницаемости с 1003,53 до 0,08 мД.

Таким образом, в изученных породах наибольшее влияние на формирование фильтрационно-емкостных свойств оказали разнонаправленные постседиментационные изменения. Улучшающие пористость пород преобразования проявлены:

- в слабом уплотнении пород;

- образовании и раскристаллизации каолинита в поровом пространстве и его частичной перекристаллизации из первичного глинисто-слюдистого агрегата (с образованием микропор в каолинитовой массе);

- растворении зёрен полевых шпатов и обломков пород с образованием внутризерновых пор. 
Фотографии шлифов из скв. 445 Лодочного месторождения, слева - без анализатора; справа - с анализатором.
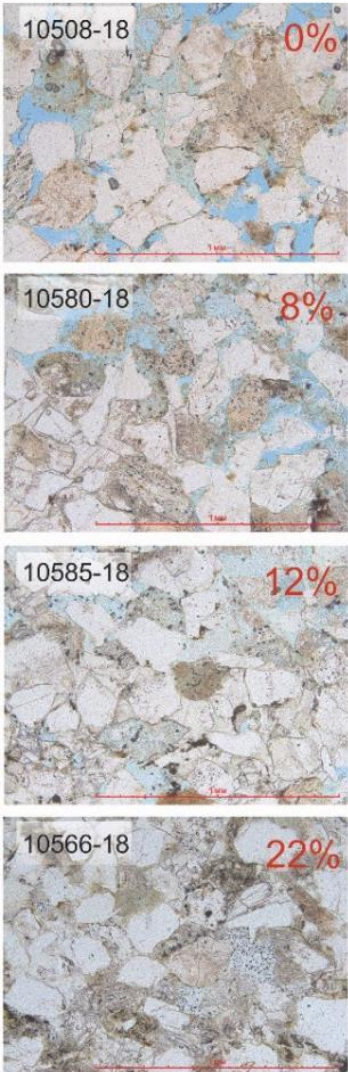

\% - содержание карбонатного цемента от площади шлифа
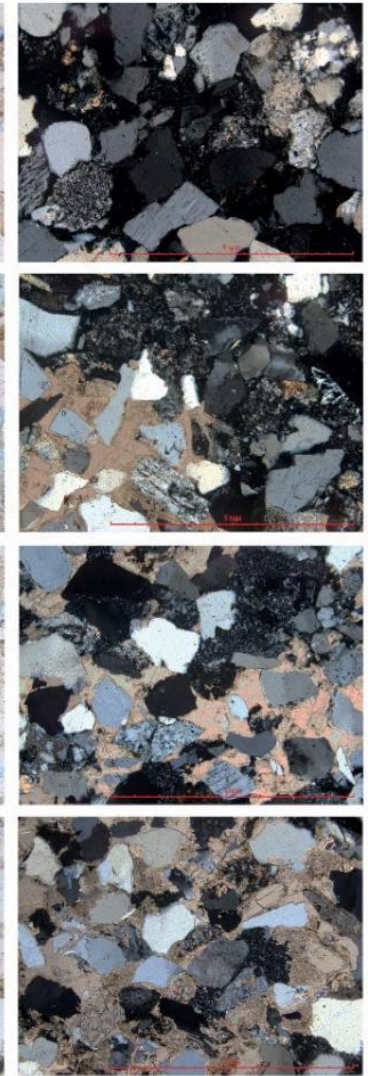

Pис. 7. Песчаники из пласта Як-V. Слева приведены ва - диаграммы соотношений пустотно-поров стости и проницаемости (внизу)

Fig. 7. Sandstones from the Yak-V layer. On the left - sandstones thin sections photos from the distribution channel facies, on the right - diagrams of the relationships between the pore space and cement (top) and the porosity and permeability dependence (bottom)

Из вторичных изменений, уменьшающих поровое пространство, необходимо отметить развитие карбонатных минералов, приводящих к сокращению и выполнению минеральным веществом пор и появлению практически непроницаемых участков.

\section{Заключение}

Изучение кернового материала из песчаных пластов Лодочного месторождения показало, что во время образования яковлевской свиты на территории существовала дельтовая система флювиального типа. Формирование отложений происходило в условиях смены фациальных обстановок в диапазоне от субаэральной до субаквальной части дельтовой равнины на фоне незначительных колебаний уровня моря и постепенной проградации дельты.

Среди всего многообразия комплекса фаций дельтовой системы наиболее интересными, с точки зрения фильтрационно-емкостных характеристик, оказались песчаники распределительных русел дельтовых проток u промоин, сформированные в условиях действия однонаправленных потоков. Песчаники этой фации сложены мелко- и среднезернистыми разностями с невыдержанной косой однонаправленной и плоскопараллельной слоистостью ряби течения с преимущественно хорошей и средней сортировкой материала. Проницаемость русловых песчаных отложений в среднем составляет около 400 мД, в отдельных образцах достигая значений свыше 2000 мД. Среди песчаных коллекторов на Лодочном месторождении песчаники русел выделяются наибольшей толщиной прослоев до 10 м и более.

Изучение вещественного состава песчаников яковлевской свиты с использованием поляризационного микроскопа показало отсутствие смены питающих провинций на всём этапе формирования изучаемой свиты, о чём свидетельствует относительное постоянство состава обломочной части.

Анализ проявлений постседиментационных изменений позволил сделать выводы о влиянии вторичной карбонатизации на коллекторские свойства пластов яковлевской свиты. Наличие карбонатного цемента с неравномерным пятнистым характером распределения объясняет ухудшение емкостных параметров песчаников. С увеличением содержания карбонатов в пласте снижается их пористость и проницаемость, так на Лодочном месторождении в песчаниках пласта Як$\mathrm{V}$, изначально сформированных в одинаковых фациальных условиях, проницаемость варьирует в диапа- 
зоне от 0,02 мД в известковистых разностях до 2195 мД в песчаниках с каолинитовым цементом.

Авторы выражают признательность сотрудникам лаборатории физики пласта и лаборатории седиментологии

\section{СПИСОК ЛИТЕРАТУРЫ}

1. Япаскурт О.В. Стадиальный анализ минеральных свидетелей динамики процессов формирования и эволюции вещества осадочных пород - перспективное научное направление литологии и нефтегазовой геологии // Георесурсы. - 2016. - Т. 18. - № 1. - С. $64-68$.

2. Юсеф И.М., Морозов В.П. Характеристика песчаников газонефтяных резервуаров верхнего триаса Сирии с использованием лабораторных методов анализа // Георесурсы. - 2017. T. 19. - № 4. - Ч. 2. - C. 356-363.

3. Fic J.., Pedersen K.P. Reservoir characterization of a «tight» oil reservoir, the middle Jurassic Upper Shaunavon Member in the Whitemud and Eastbrook pools, SW Saskatchewan // Marine and Petroleum Geology. - 2013. - V. 44. - P. 41-59.

4. Diagenesis and reservoir quality of the lower Cretaceous Quantou Formation tight sandstones in the southern Songliao Basin, China / K. Xi, K.Y. Cao, J. Jahren, R. Zhu, K. Bjørlykke, B.G. Haile, L. Zheng, H. Hellevang // Sedimentary Geology. - 2015. - V. 330. - P. 90-107.

5. Poursoltania M.R., Gibling M.R., Pe-Piper G. Diagenesis, burial history, and hydrocarbon potential of Cambrian sandstone in the northern continental margin of Gondwana: a case study of the Lalun Formation of central Iran // Journal of Asian Earth Sciences. -2019 . - V. 172. - P. 143-169

6. Zhang Y., Pe-Piper G.J.W. How sandstone porosity and permeability vary with diagenetic minerals in the Scotian Basin, offshore eastern Canada: Implications for reservoir quality // Marine and Petroleum Geology. - 2015. - V. 63. - P. 28-45.

7. Xiong D., Azmy K., Blamey N.J.F. Diagenesis and origin of calcite cement in the Flemish Pass Basin sandstone reservoi (Upper Jurassic): Implications for porosity development // Marine and Petroleum Geology. - 2016. - V. 70. - P. 93-118.

8. Impacts of sedimentology and diagenesis on pore structure and reservoir quality in tight oil sandstone reservoirs: Implications for macroscopic and microscopic heterogeneities / J. Qaio, J. Zeng, S. Jiang, Y. Wang // Marine and Petroleum Geology. - 2020. V. 111. - P. 279-300.

9. Impacts of lithologic characteristics and diagenesis on reservoi quality of the 4th member of the Upper Triassic Xujiahe Formation tight gas sandstones in the western Sichuan Basin, southwest China / Y. Yu, L. Lin, Ch. Zhai, H. Chen, Y. Wang, Y. Li, X. Deng // Marine and Petroleum Geology. - 2019. - V. 107. - P. 1-19.

10. Hillier S. Quantitative analysis of clay and other minerals in sandstones by X-ray powder diffraction (XRPD) // Clay minera cements in sandstones. Special Publication / Eds. R. Worden, S. Morad. - Oxford, International Association of Sedimentologist 2003. - P. 213-251.

11. Япаскурт О.В. Предметаморфические изменения осадочных пород в стратисфере: процессы и факторы. - М.: ИНФРА-М, 2018. - $259 \mathrm{c}$.

12. Страхов Н.М. Избранные труды: Общие проблемы геологии, литологии и геохимиии. - М.: Наука, 1983. - 640 с.

13. Барабошкин Е.Ю. Практическая седиментология. Терригенные резервуары. Пособие по работе с керном. - Тверь: ООО «Издательство ГЕРС», 2011. - 152 с.

14. Reineck H.-E., Singh I.B. Depositional sedimentary environments with reference to terrigenous clastics. - Berlin; Heidelberg: Springer-Verlag, 1980. $-551 \mathrm{p}$.

\section{Информация об авторах}

Черданцева Д.А., научный сотрудник лаборатории седиментологии управления лабораторными исследованиями керна АО «ТомскНИПИнефть».

Кравченко $\boldsymbol{\Gamma . \Gamma . , ~ к а н д и д а т ~ г е о л о г о - м и н е р а л о г и ч е с к и х ~ н а у к , ~ з а в е д у ю щ и и ̆ ~ л а б о р а т о р и е и ̆ ~ с е д и м е н т о л о г и и ~ у п р а в - ~}$ ления лабораторными исследованиями керна АО «ТомскНИПИнефть».

Краснощекова Л.A., кандидат геолого-минералогических наук, доцент отделения геологии Инженерной школы природных ресурсов Национального исследовательского Томского политехнического университета.
АО «ТомскНИПИнефть» за обсуждение результатов проведенных исследований и аналитический материал, предоставленный для работы, а также благодарят рецензента, комментарии которого помогли улучиить статью.

15. Алексеев В.П. Атлас субаквальных фаций нижнемеловых Изд-во УГГУ, 2014. - 284 с.

16. Логвиненко Н.В., Сергеева Э.И. Методы определения осадочных пород. - Л.: Недра, 1986. - 240 с.

17. Шванов В.Н. Петрография песчаных пород (компонентный состав, систематика и описание минеральных видов). - Л.: Недра, 1987. - 269 с.

18. Ботвинкина Л.Н. Слоистость осадочных пород. Тр. ГИН АН СССР. - М.: Наука, 1962. - Вып. 59. - 542 с.

19. Einsele G. Sedimentary basins: evolution, facies, and sediment budget. - Berlin: Springer-Verlag, 2000. - $792 \mathrm{p}$.

20. Копелиович А.В. Эпигенез древних толщ юго-запада Русской платформы // Труды Акад. наук СССР. Геол. ин-т. Вып. 121. - М.: Наука, 1965. - 312 с.

21. Страхов Н.М., Залмансон Э.С., Глаголева М.А. Очерки геохимии верхнепалеозойских отложений гумидного типа (опыт фациально-геохимического исследования). - М.: Изд-во АН CCCP, 1959. $-223 \mathrm{c}$.

22. Ежова А.В. Литология. Краткий курс. - Томск: Изд-во Томского политехнического университета, 2014. - 102 с.

23. Япаскурт О.В. Генетическая минералогия и стадиальный анализ процессов осадочного породо- и рудообразования. М.: ИНФРА-М, 2017. - $356 \mathrm{c}$

24. Мельник И.А., Недоливко Н.М., Зимина С.В. Вторичные карбонаты юрских песчаных отложений как показатели продуктивности палеозоя // Известия Томского политехнического университета. Инжиниринг георесурсов. - 2020. - Т. 331. - № 3. - С. 32-38. DOI: https://doi.org/10.18799/24131830/2020/3/2529.

25. Постседиментационные преобразования нижнемеловых отложений Большехетской впадины (Западная Сибирь) / Ю.В. Титов, Г.Х. Шайхутдинова, С.В. Астаркин, В.В. Колпаков, Н.В. Кожевникова // Литосфера. - 2019. - № 1. - С. 48-58. URL: https://doi.org/10.24930/1681-9004-2019-19-1-48-58 (дата обращения 15.09.2020).

26. Coupling relationship between sandstone reservoir densification and hydrocarbon accumulation: a case from the Yanchang Formation of the Xifeng and Ansai areas, Ordos Basin / M. Liu, Z. Liu, J. Liu, W. Zhu, Y. Huang, X. Yao // Petroleum Exploration and Development. - 2014. - V. 41. - P. 185-192.

27. How sandstone porosity and permeability vary with diagenetic minerals in the Scotian Basin, offshore eastern Canada: implications for reservoir quality / Y. Zhang, P.G. Piper, D.J.W. Piper // Marine and Petroleum Geology. - 2015. - V. 63. P. 28-45.

28. Sandstone diagenesis and reservoir quality prediction: models, myths, and reality / T.R. Taylor, M.R. Giles, L.A. Hathon, T.N. Diggs, N.R. Braunsdorf, G.V. Birbiglia // AAPG Bulletin. 2010 - V. 94 - P. 1093-1132.

29. Diagenesis of a tight gas sand reservoir: Upper Cretaceous Mesaverde Group, Piceance Basin, Colorado / M.T. Storker, B.N. Harris, C.W. Elliott, M.J. Wampler // Marine and Petroleum Geology. - 2013. - V. 40. - P. 48-68.

Поступила 22.09.2020 2. отложений Западной Сибири (ХМАО-Югра). - Екатеринбург: 
UDC 552.513: 552.144: 551.3.051

\title{
THE YAKOVLEVSKAYA SUITE OIL-BEARING SANDSTONE FORMATION CONDITIONS IN THE LODOCHNOE OIL FIELD
}

\author{
Daria A. Cherdantseva 1 , \\ cherdantsevada@tomsknipi.ru
}

\author{
Grigory G. Kravchenko1, \\ kravchenkogg@tomsknipi.ru \\ Lyubov A. Krasnoshchekova², \\ krasnl@tpu.ru \\ 1 Tomsk oil and gas research and design institute, \\ 72, Mira avenue, Tomsk, 634027, Russia. \\ 2 National Research Tomsk Polytechnic University, \\ 30, Lenin avenue, Tomsk, 634050, Russia.
}

The relevance of the research is caused by the need to expand the Russian Federation resource potential due to increase in the number of hydrocarbon deposits. Today, oil is a mineral resource, which achieved production levels are not adequately provided with developed field's reserves. The productive reservoirs structure detailed study within the Vankor fields group in the future will provide an opportunity for forecasting and discovering new hydrocarbon deposits within the Lower Cretaceous Siberian deposits.

The main aim of the research is to determine the productive sandstone formation conditions according to the core material study, to study the field structure heterogeneity causes and to identify their characteristic signs for the subsequent forecast of the Lower Cretaceous oil deposits in the area of the Krasnoyarsk region.

Objects: oil-bearing sandstone layers in the Yakovlevskaya suite, Lodochnoe oil and gas deposit.

Methods: thin sections petrographic analysis, grain size analysis, facies and formation analysis, filtration-capacitive properties core study. Results. The Upper and Lower Yakovlevskaya subsuites sandstones material composition was studied by petrographic analysis, their comparative characteristics are given. The post-sedimentation processes influence on the studied sedimentary rock appearance formation is determined. A facies model that most closely describes the productive layers sedimentation conditions is proposed. The influence of facies sedimentation conditions and post-sedimentary rocks transformations on the sandstones filtration-capacitive characteristics is established. The reasons for the carbonated interlayers presence in fluvial deposits are explained. Conclusions are drawn about the possibility of predicting the Lower Cretaceous sediments productivity accumulated in various facies environments, using the Yakovlevskaya suite in Lodochnoe deposit as an example.

\section{Key words:}

Sandstone, diagenesis, Yakovlevskaya suite, alluvial environment, Krasnoyarsk region.

The authors express their deep gratitude to the petrophysics and sedimentology laboratories staff for valuable comments and the analytical material provided for work.

\section{REFERENCES}

1. Yapaskurt O.V. Stage Analysis of Minerals that Witnessed Formation and Evolution Dynamics of Sedimentary Rocks - Perspective Scientific Direction of Lithology and Geology of Oil and Gas. Georesources, 2016, vol. 18, No. 1, pp. 64-68. Available at: https://geors.ru/media/ pdf/12_Yapaskurt_en.pdf (accessed 20 September 2020).

2. Yousef I.M., Morozov V.P. Characteristics of Upper Triasic Sandstone Reservoirs in Syria Using Analysis of Laboratory Methods. Georesursy, 2017, vol. 19, No. 4, part 2, pp. 356-363. Available at: https://geors.ru/media/pdf/2_Morozov_en.pdf (accessed 20 September 2020).

3. Fic J., Pedersen K.P. Reservoir characterization of a «tight» oil reservoir, the middle Jurassic Upper Shaunavon Member in the Whitemud and Eastbrook pools, SW Saskatchewan. Marine and Petroleum Geology, 2013, vol. 44, pp. 41-59.

4. Xi K., Cao K.Y., Jahren J., Zhu R., Bjørlykke K., Haile B.G., Zheng L., Hellevang H. Diagenesis and reservoir quality of the lower Cretaceous Quantou Formation tight sandstones in the southern Songliao Basin, China. Sedimentary Geology, 2015, vol. 330, pp. $90-107$.

5. Poursoltania M.R., Gibling M.R., Pe-Piper G. Diagenesis, burial history, and hydrocarbon potential of Cambrian sandstone in the northern continental margin of Gondwana: a case study of the Lalun Formation of central Iran. Journal of Asian Earth Sciences, 2019, vol. 172, pp. 143-169.
6. Zhang Y., Pe-Piper G.J.W. How sandstone porosity and permeability vary with diagenetic minerals in the Scotian Basin, offshore eastern Canada: implications for reservoir quality. Marine and $\mathrm{Pe}$ troleum Geology, 2015, vol. 63, pp. 28-45.

7. Xiong D., Azmy K., Blamey N.J.F. Diagenesis and origin of calcite cement in the Flemish Pass Basin sandstone reservoir (Upper Jurassic): implications for porosity development. Marine and Petroleum Geology, 2016, vol. 70, pp. 93-118.

8. Qaio J., Zeng J., Jiang S., Wang Y. Impacts of sedimentology and diagenesis on pore structure and reservoir quality in tight oil sandstone reservoirs: implications for macroscopic and microscopic heterogeneities. Marine and Petroleum Geology, 2020, vol. 111, pp. 279-300.

9. Yu Y., Lin L., Zhai Ch., Chen H., Wang Y., Li. Y., Deng X. Impacts of lithologic characteristics and diagenesis on reservoir quality of the $4^{\text {th }}$ member of the Upper Triassic Xujiahe Formation tight gas sandstones in the western Sichuan Basin, southwest China. Marine and Petroleum Geology, 2019, vol. 107, pp. 1-19.

10. Hillier S. Quantitative analysis of clay and other minerals in sandstones by X-ray powder diffraction (XRPD). Clay mineral cements in sandstones. Special Publication. Eds. R. Worden, S. Morad. Oxford, International Association of Sedimentologist, 2003. pp. 213-251.

11. Yapaskurt O.V. Predmetamorficheskie izmeneniya osadochnykh porod $v$ stratisfere: protsessy i faktory [Submetamorphic changes 
in sedimentary rocks in the stratosphere: processes and factors]. Moscow, INFRA-M Publ., 2018. 259 p.

12. Strakhov N.M. Izbrannye trudy: obshchiye problemy geologii, litologii i geokhimiii [Selected works: general problems of geology, lithology and geochemistry]. Moscow, Nauka Publ., 1983. 640 p.

13. Baraboshkin E.Yu. Prakticheskaya sedimentologiya. Terrigennye rezervuary. Posobie po rabote s kernom [Practical sedimentology. Terrigenous reservoirs. Manual for working with core]. Tver, GERS Publ. House, 2011. $152 \mathrm{p}$

14. Reineck H.-E., Singh I.B. Depositional Sedimentary Environments with reference to terrigenous clastics. Berlin, Heidelberg, Springer-Verlag, $1980.551 \mathrm{p}$.

15. Alekseev V.P. Atlas subakvalnykh fatsiy nizhnemelovykh otlozheniy Zapadnoy Sibiri (KHMAO-Yugra) [Atlas of subaquatic facies of the Lower Cretaceous sediments of Western Siberia (Khanty-Mansi Autonomous Okrug-Yugra)]. Yekaterinburg, Ural State Mining University Publ. House, 2014. 284 p.

16. Logvinenko N.V., Sergeeva E.I. Metody opredeleniya osadochnykh porod [Methods for the determination of sedimentary rocks]. Leningrad, Nedra Publ., 1986. 240 p.

17. Shvanov V.N. Petrografiya peschanykh porod (komponentny sostav, sistematika i opisaniye mineralnykh vidov) [Sandstone petrography (component composition, systematics and description of mineral species)]. Leningrad, Nedra Publ., 1987. 269 p.

18. Botvinkina L.N. Sloistost osadochnykh porod. Trudy GIN AN SSSR [Layering of sedimentary rocks. GIN AN USSR Proc.]. Moscow, Nauka Publ., 1962. Issue. 59, 542 p.

19. Einsele G. Sedimentary basins: evolution, facies, and sediment budget. Berlin, Springer-Verlag, 2000, 792 p.

20. Kopeliovich A.V. Epigenez drevnikh tolshch yugo-zapada Russkoy platform. Trudy Akademii nauk SSSR. Geol. in-t [Epigenesis of ancient strata the Russian platform south-west. Trudy Akad. Sciences of the USSR. Geol. in-t]. Moscow, Nauka Publ., 1965. Iss. 121, $312 \mathrm{p}$.

21. Strakhov N.M., Zalmanson E.S., Glagoleva M.A. Ocherki geokhimii verkhnepaleozoyskikh otlozheniy gumidnogo tipa (opyt fatsialno-geokhimicheskogo issledovaniya) [Essays on the geochemistry of the Upper Paleozoic deposits of the humid type (ex- perience of facies-geochemical studies)]. Moscow, Academy of Sciences of the USSR Publ. House, 1959. 223 p.

22. Ezhova A.V. Litologiya. Kratkij kurs [Lithology. Short course]. Tomsk, Tomsk Polytechnic University Publ. house, 2014, 102 p.

23. Yapaskurt O.V. Geneticheskaya mineralogiya $i$ stadialny analiz protsessov osadochnogo porodo- $i$ rudoobrazovaniya [Genetic mineralogy and stage analysis of sedimentary rock and ore formation processes]. Moscow, INFRA-M Publ., 2017, 356 p.

24. Melnik I.A., Nedolivko N.M., Zimina S.V. Secondary carbonates of Jurassic sand deposits as indicators of the Paleozoic productivity. Bulletin of the Tomsk Polytechnic University. Geo Assets Engineering, 2020, vol. 331, no. 3, pp. 32-38. DOI: https://doi.org/10.18799/24131830/2020/3/2529.

25. Titov Yu.V., Shayhutdinova G.H., Astarkin S.V., Kolpakov V.V., Kozhevnikova N.V. Postsedimentatsionnye preobrazovaniya nizhnemelovykh otlozheniy Bolshekhetskoy vpadiny (Zapadnaya Sibir) [Manifestations of post-sedimentation processes in the Lower Cretaceous sediments of Bolshekhetskaya depression (Western Siberia)]. Litosfera, 2019, no. 1, pp. 48-58.

26. Liu M., Liu Z., Liu J., Zhu W., Huang Y., Yao X. Coupling relationship between sandstone reservoir densification and hydrocarbon accumulation: a case from the Yanchang Formation of the Xifeng and Ansai areas, Ordos Basin. Petroleum Exploration and Development, 2014, vol. 41, pp. 185-192.

27. Zhang Y., Piper P.G., Piper D.J.W. How sandstone porosity and permeability vary with diagenetic minerals in the Scotian Basin, offshore eastern Canada: implications for reservoir quality. Marine and Petroleum Geology, 2015, vol. 63, pp. 28-45.

28. Taylor T.R., Giles M.R., Hathon L.A., Diggs T.N., Braunsdorf N.R., Birbiglia G.V. Sandstone diagenesis and reservoir quality prediction: models, myths, and reality. AAPG Bulletin, 2010, vol. 94, pp.1093-1132.

29. Storker M.T., Harris B.N., Elliott C.W., Wampler M.J. Diagenesis of a tight gas sand reservoir: Upper Cretaceous Mesaverde Group, Piceance Basin, Colorado. Marine and Petroleum Geology, 2013, vol. 40, pp. $48-68$.

Received: 22 September 2020.

\section{Information about the authors}

Daria A. Cherdantseva, reseracher, Tomsk oil and gas research and design institute.

Grigory G. Kravchenko, Cand. Sc., head of the laboratory, Tomsk oil and gas research and design institute.

Lyubov A. Krasnoshchekova, Cand. Sc., associate professor, National Research Tomsk Polytechnic University. 